\title{
Model considerations on physico-chemical nature of protein-nucleic acid contacts through amino acid carboxylic groups: spectroscopic data
}

\author{
Svitlana P. Samijlenko, Iryna M. Kolomiets, Igor V. Kondratyuk, Andrij V. Stepanyugin
}

Institute of Molecular Biology and Genetics of National Academy of Sciences of Ukraine

150 vui. Acad. Zabolotnobo, Kyiv, 252143, Ukraine

\begin{abstract}
This paper generalizes the results of a series of the works on spectroscopic (IR, UV, NMR, Raman) investigations of complexes of nucleotide bases, their numerous methyl and glycosyl derivatives with amino acid carboxylic groups modelling point protein-nucleic acid contacts. The specificity of interactions between bases and two forms of carboxylic group - neutral and deprotonated - was determined. The structures of the complexes investigated were established, and the role of various atomic groups in their formation was elucidated as well. Special consideration has been given to the frequent occurrence of proton transfer in the studied complexes. The significance of the data obtained in understanding of elementury mechanisms of protein-nucleic acid inteructions is discussed.
\end{abstract}

Although the number of investigations on structures of protein-nucleic acid complexes by X-ray $[1-6]$ and NMR spectroscopy $[4-9]$ is continuously increasing, not in every case it is possible to distinguish unambiguously the fine architecture of point proteinnucleic acid contacts. Therefore, the study on elementary mechanisms of protein-nucleic acid recognition in more simple model systems $[10-22]$ remains aciual.

In the present brief survey we try to gencralize the main physico-chemical features of interactions in the complexes modelling recognition of nucleotide bases, their nuclcosides and a variety of their methyl derivatives by carboxylic groups of Asp and Glu in DMSO. The use of DMSO as a solvent allows us to observe rather strong interactions which exceed its interactions with the bases and amino acid carboxylic groups. The systematic studies of these complexes were conducted by means of UV, IR and NMR spcctroscopies over the last few years [23-31]. Interpretations of the results were supported by the model semiempirical quantum-mechanical calculations [32].

(C) S. P. SAMHLENKO, I. N. KOLAMIETS, I. v. KONDRATYUK.
Among non-substituted nucleotide bases and nucleosides only Cyt, weakly interacting with deprotonated carboxylic group (carboxylate-ion), was shown to form the strong complex with neutral carboxylic group through two $\mathrm{H}$-bonds involving $\mathrm{N} 3$ atom and amino group or $\mathrm{N} 1 \mathrm{H}$ and $\mathrm{C}=\mathrm{O}$ groups (according to the AM1 calculations [32] the latter scheme is prevailing) (Fig. 1). The results of IR and Raman investigations of solid state complexes of cytosine and amino acid carboxylic groups $[23,28]$, as well as ${ }^{13} \mathrm{C}$ NMR study in DMSO [25] evidence the proton transfer from carboxylic group to the base along the $\mathrm{OH} . . \mathrm{N} 3$ bond. Moreover, it was shown that in the triple complex f-Asp:Cyt:m ${ }^{9}$ Gua amino acid carboxylic group, binding to $\mathrm{Cyt}$, loosens $\mathrm{H}$-bonds inside the base pair.

Quite the contrary, the other bases and nucleosides form specific complexes with carboxylate-ion, their interactions with neutral carboxylic group were not observed. Nevertheless, such interactions may be realized in less polar environment $|33|$ in which the solvatation of the ligands is lower.

It was demonstrated that imino and amino groups of the bases have a dominant role in formation of their complexes with carboxylate-ion. The monomethylation of Gua and Ade amino groups doesn't 
change the character of interaction with carboxylateion, increasing it considerably. To the point, the significant role of inversion and anisotropic rotation of the nucleotide bases' amino groups in DNA structure and fuctioning is discussed in the papers [34--38 ].<smiles></smiles>

$a$

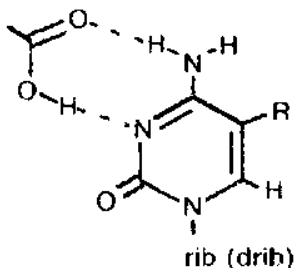

c<smiles>CC(=O)ONCOc1ccc(N)cn1</smiles><smiles></smiles>

d

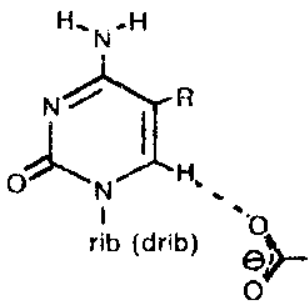

e

Fig. 1. Schemes of the complexes of: cytosine, 1-methylcytosine 5 -methylcytosine, 1,5-dinethylcytosine $(a, b)$, cytidine, deoxycytidine, 5-methyldeoxycytidine $(c)$ with neutral carboxylic group; cytosine, 5-methylcytosine $(d)$, cytidine, deoxycytidine, 5-methyldeoxycytidine (e) with carboxylate-ion. Hereinafter abbreviations are $\mathrm{R}=\mathrm{H}, \mathrm{CH}_{3} ; \mathrm{rib}$ (drib) - ribose (deoxyribose)
Carboxylate-ion forms highly specific complex with $\mathrm{m}^{9} \mathrm{G}$ ua and $\mathrm{G}$ through two $\mathrm{H}$-bonds involving the $\mathrm{N} 1 \mathrm{H}$ imino and $\mathrm{N} 2 \mathrm{H}$ amino groups, Ade $-\mathrm{N} 6 \mathrm{H}$ amino and $\mathrm{N} 7 \mathrm{H}$ imino groups [39] (the $\mathrm{N} 9 \mathrm{H} \rightarrow \mathrm{N} 7 \mathrm{H}$ tautomeric transition of Ade complexed with carboxylate-ion was borne out by the quantum-chemical calculations [32]), $\mathrm{Hyp}-\mathrm{N} 1 \mathrm{H}$ and/or $\mathrm{N} 9 \mathrm{H}$ imino groups, $\mathrm{I}-\mathrm{N} 1 \mathrm{H}$ imino group, $\mathrm{X}$ and $\mathrm{m}^{9} \mathrm{Xan}-\mathrm{N} 3 \mathrm{H}$ imino groups, $\mathrm{Xan}-\mathrm{N} 3 \mathrm{H}$ and $\mathrm{N} 9 \mathrm{H}$ imino groups, $\mathrm{m}^{3} \mathrm{Xan}-\mathrm{N} 9 \mathrm{H}$ imino group (the $\mathrm{N} 7 \mathrm{H} \rightarrow \mathrm{N} 9 \mathrm{H}$ tautomeric transition of Xan and $\mathrm{m}^{3}$ Xan complexed with carboxylate-ion was confirmed by quantum-chemical simulations [32 ]), Ura and Thy $-\mathrm{N} 1 \mathrm{H}$ and/or N3H imino groups, $\mathrm{U}$ and $\mathrm{T}-\mathrm{N} 3 \mathrm{H}$ imino groups (Fig. 2). The determining role of bases' imino group as proton donor under $\mathrm{H}$-bonded complex formation with carboxylate-ion is demonstrated by complete suppression of interactions with methylated at imino groups $\mathrm{m}^{\prime} \mathrm{G}$, $\mathrm{m}^{\mathrm{l}} \mathrm{I}, \mathrm{m}_{2}{ }^{1,3} \mathrm{Ura}, \mathrm{m}_{2}{ }^{1,7} \mathrm{Gua}, \mathrm{m}^{9}$ Ade, as well as by noticeable weakening the interaction of $\mathrm{m}^{1} \mathrm{Cyt}$ with carboxylic group and $m^{1} \mathrm{Ura}, \mathrm{m}^{3} \mathrm{Ura}, \mathrm{m}^{1}$ Thy with carboxylate-ion .

The methylation of pyrimidine bases at the $\mathrm{C} 5$ position does not change the schemes of interactions in the complexes formed, the stability of the complexes of $\mathrm{m}^{5} \mathrm{Cyt}$ and $\mathrm{m}_{2}{ }^{1,5} \mathrm{Cyt}$ with carboxylic group being significantly increased as compared to Cyt and $\mathrm{m}^{1}$ Cyt [27].

In general, almost all substitutions of the bases which don't involve the essential distortions of their rings retain specificity as to binding with neutral and deprotonated carboxylic group. To the contrary, methylations of the bases which change cardinally the ring structure (the $\mathrm{N} 1$ and $\mathrm{N} 3$ positions of Ade N3 - Gua, N3 - Cyt, N7 - purine nucleosides) cause alterations of types of the complexes formed (Fig. 3) and, as a rule, the reversion of the specific interactions with two forms of carboxylic group.

It might be well to point out the involvement of the $\mathrm{C} 8 \mathrm{H}$ protons of $\mathrm{m}^{7} \mathrm{I}, \mathrm{m}^{7} \mathrm{X}$, and the $\mathrm{C} 6 \mathrm{H}$ protons of pyrimidine bases in weak $\mathrm{H}$-bonding with carboxylate-ion [30].

Carboxylate-ion was shown to interact with the $\mathrm{O}^{\prime} \mathrm{H}, \mathrm{O3}^{\prime} \mathrm{H}$ and $\mathrm{O}^{\prime} \mathrm{H}$ glycosylic hydroxyls of nucleosides [40]. In the case of ribosides it forms two cooperative $\mathrm{H}$-bonds with $\mathrm{O}^{\prime} 2 \mathrm{H}$ and $\mathrm{O}^{\prime} \mathrm{H}$ groups. It should be noted that ribose (deoxyribose) and the base of nucleosides affect mutually their interactions with carboxylate-ion.

The obtained set of physico-chemical features of point protein-nucleic acid contacts is consistent with $\mathrm{X}$-ray and NMR data concerning detailed architecture of nucleic acids complexes with various enzymes, regulatory proteins and drugs of peptidic nature and 


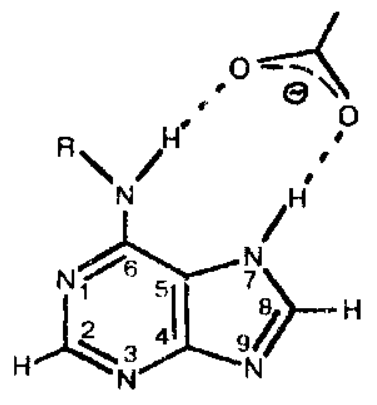

$a$

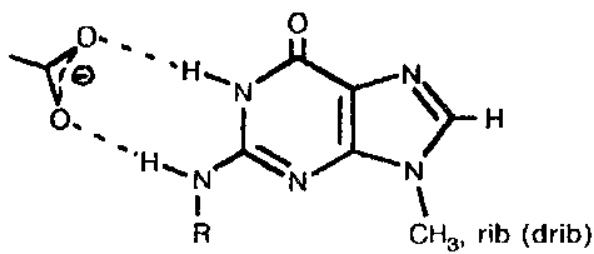

$b$

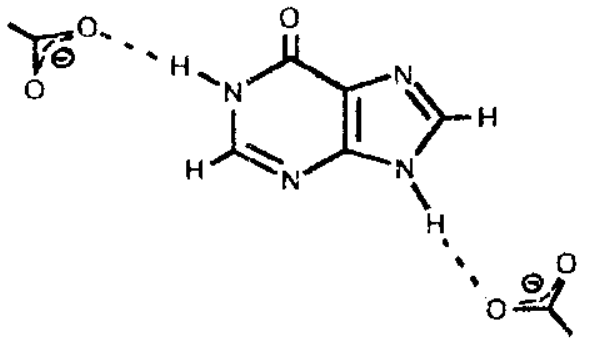<smiles></smiles>

$d$

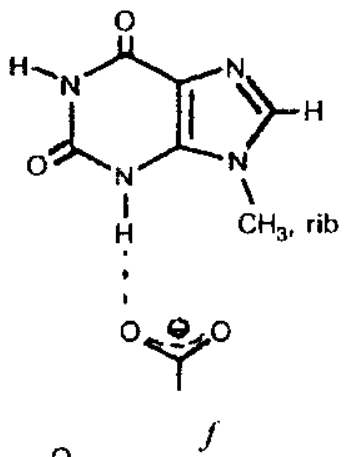<smiles>[R]c1c2n(c(=O)[nH]c1=O)[CH]OC(C)O[C@H]2O</smiles>

$g^{\prime}$

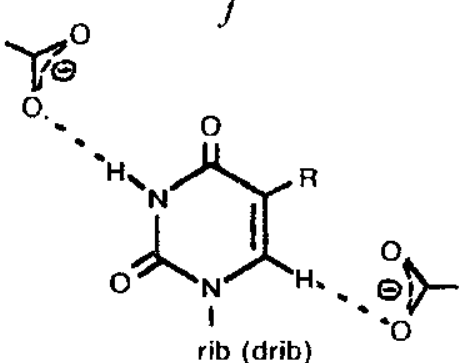

$h$

Fig. 2. Schemes of the complexes of: adenine, 6-methyladenine (a), 9-methylguanine, 2,9-dimethylguanine, guanosine, deoxyguanosine, 2 -methylguanosine $(d)$, hypoxanthine $(c)$, inosine, deoxyinosine $(d)$, xanthine $(e)$, 9-methylxanthine, xanthosine $(f)$, uracil, thymine $(g)$, uridine, deoxyuridine, thymidine, ribothymidine $(h)$ with carboxylate-ion 


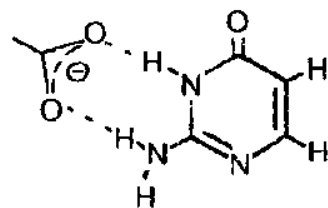

$a$

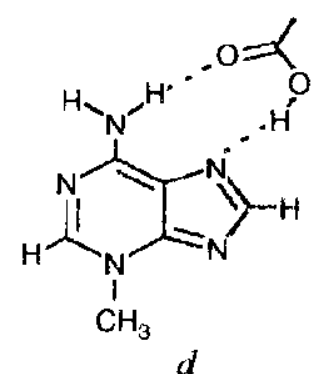

$d$

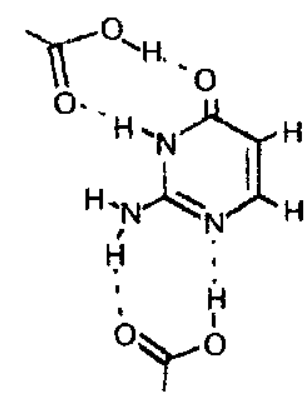

b<smiles></smiles>

H, rib

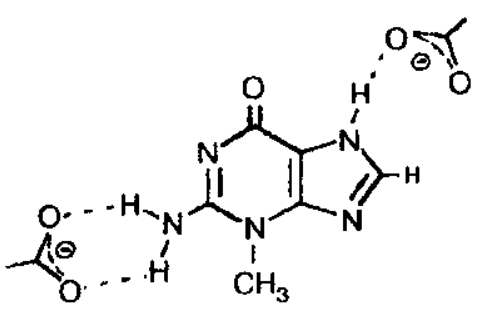<smiles>Cn1c([C@H]2CC(=O)O2)[n+](C)c2c(=O)[nH]cnc21</smiles><smiles></smiles><smiles></smiles>

$g$

h

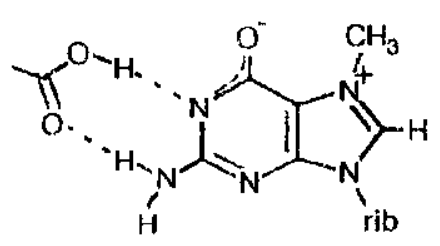

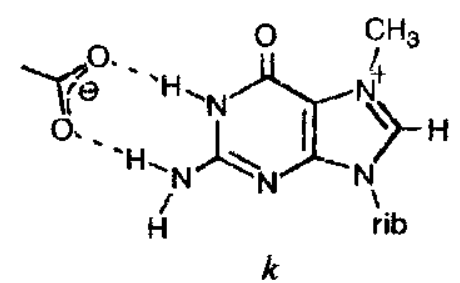

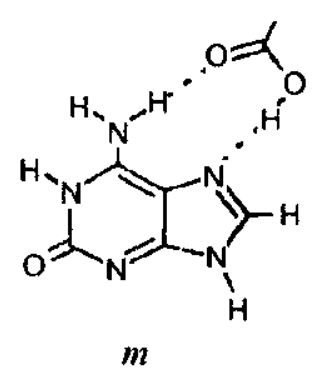

\%

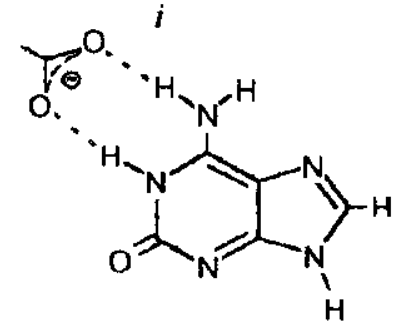

$j$

Fig. 3. Schemes of the complexes of: isocytosine $(a), 3$-methylguanine $(f), 7$-methylinosine $(g), 7$-methylxanthosine $(i)$, 7-methylgua $(k)$, isoguanine $(l)$ with carboxylate-ion; isocytosine $(b), 1$-methyladenine, 1-methyladenosine $(c), 3$-methyladenine $(d)$, 3-methylguanir 7-methylinosine $(h), 7$-methylguanosine $(i)$, isoguanine $(m)$ with neutral carboxylic group 
could be applied to refincment of their structures and functioning. These data may be of use for design of biologically active substances of peptidic or nucleotide nature with aimed actions and understanding their therapeutic effects. There is the information on the participation of neutral and deprotonated forms of carboxylic group of Asp and Glu in formation of real protcin-nucleic acid complexes. To cite examples, the complexes of 3-and 7-alkyl purine bases with reparation cnzymes 141,42$]$, glutaminyl-tRNA synthetase with $\operatorname{tRNA}^{\text {(iln }}[43,44]$, seryl-tRNA synthetase with tRNA ${ }^{\text {Ser }}[45,46 \mid$, ribonuclease $T$, with 2 -GMP [47], RNA with the coat protein in TMV [48], DNA with the glucocorticoid receptor [49], Hhal DNA cytosine5-methyltrasfcrase with its target cylosine and cofactor $|50|$, mutation of Asn $\rightarrow$ Asp in thymidylate synthase converting the enzyme to a deoxycytidylate methylase [51], and others.

The most prominent feature of the complexes studicd is a very commion occurrence of proton transfer [31 ]. The protonation of bases on account of carboxylic group has been proved for Cyt, $\mathrm{m}^{5} \mathrm{Cyt}$, $m^{1}$ Ade, $m^{3}$ Ade, $m^{\prime} A, m^{7} G$ (A form) and $m^{7} l$. The proton transfer from bases to carboxylate-ion was observed in the complexes of $m^{3} \mathrm{Cyt}, \mathrm{m}^{3} \mathrm{Gua}, \mathrm{m}^{7} \mathrm{G}$ (B form), Hyp, Xan, $m^{9} X a n$ and $X$ with deprotonated carboxylic group. There are some indications that Ura, Thy, isoGua, isoCyt are deprotonated in the complexes with carboxylate-ion.

Up-to-datc physico-chemical biology attaches a great importance to proton transfer processes $152-$ 54 ], which determine dynamic aspects of interactions between biopolymers, especially in nucleoproteid complexes.

It might be worth pointing that proton transfer processes determined by two well structurc of the $\mathrm{H}$-bond potentials are substantially nonlinear and environmental dependent. The proton polarizability of such $\mathrm{H}$-bonds (ability of shifting along the $\mathrm{H}$-bonds) may exceed electron polarizability by two orders [55] and increases while chains of $\mathrm{H}$-bonds are formed because of collective motion of protons [56 ]. There is an idea, that chains of $\mathrm{H}$-bonds with such potentials in real biopolymers and their complexes may be one of the causative factors of their non-linear dynamics and the possible routes for the signals of long-range control of biochemical reactions. It is the complexes investigated that give an impetus to conformational transitions and biochemical transformations at long distances.

Much part of the work was sponsored by the ISF (grant KIF100).
С. П. Самійленко, І. М. Коломісиь, І. В. Кондрапюк A. B. Cmenaнюеин

Фізико-хімічна природа модельних білково-нуклеїнових контактів через карбоксильну групу амінокислит: спектроскопічні дані

\section{Резюме}

Узагальнено результати серї робіт спектроскопічного (IУ, УФ, ЯМР, Раман) досліджения комплексів нуклеотијних основ та іхніх численних метил- та глікозилохілих а карбоксильною групою амінокислот, шо моделюють точкові білковонуклеінові контокти. встановено специрінність взасмодї основ $з$ двома формами карбоксильної групи - нейтральною та депротонованою. Визначено струкпуру досліджуваних комплехсія, а також з'ясовано роль різних атомних груп основ у іхньому формуваниі. Особливу увасу привертає поширеність ноина перенесення протона в досліджених комплексах. Обеово рюеться значення отриманих результатів для розуміния елементарних механізмів білково-нуклеїнових васмодіи.

С. А. Самойленко, Н. Н. Коломиец, И. Б. Кондранюк,

A. B. Сmeпанюеин

Физнко-химическая нрирода модельных белково-нуклеиновых контактон через карбоксильную групну аминокислог: спектроскогические данные

Резюме

Обобщены результати серии спектроскопическосо (ИК, УФ, ЯМР, Раман) исследования комплексов нуклеотидных оснований "их многонсленных метил- и гликозилпроизводных $c$ карбоксильюой сруппой аминокислот, моделируючих точечные белкояо-нуклеиновье контакты. Установлена специфичность взаимодейстоия оснований с двумя формами карбоксиноной зруппь. Определена структура исследованных комплеков, а также выяснена роль разных атомтых групп оснований в их образованин. Особое внимание обращает на себя распроснраненность яоления переноса протона в исследованных комплексах. Обсуждается значение полученниьх результатов для понимания элементарных механизмов белково-нуклеиновых взаимодействий.

\section{REFERENCES}

1. Mandel-Gutfreud $Y$., Schueler O., Margulit $H$. Comprehensive analysis of hydrogen bonds in regulatory protein DNA-complexes: In search of common principles // J. Mol. Biol.1995-253, N 2.-P. 370-382.

2. Suzuki M., Yagi N. DNA recognition code of trascription factors in the helix-turn-helix, probe helix, hormone receptor, and zinc finger families // Proc. Nat. Acad. Sci. USA.1994.-91, N 26.-P. 12357-12361.

3. Young M. A., Ravishanker G., Beverige D. L., Berman H. M Anatysis of local helix bending in crystal structure of DNA oligonucleotides and DNA-protein complexes // Biophys. J.1995.-68, N 6.--P. 2454-2468.

4. Steitz $T$. A. Structural studies of protein-liucleic acid interactoin: the sources of sequence-specific binding // Quar. Rev. Biophys. $-1990 .-23$, N 3.-P. 205-280.

5. Lehming N., Sartorius J., Kisters-Woike B. et al. Rules for protein DNA recognition for a family of helix-turn-helix proteins // Nucl. Acids and Mol. Biol -1991.—P. 114-125.

6. Frankel A. D., Mattai I. W. Rio D. C. RNA-protein interaction // Cell.-1991.-67.-P. 1041-1046. 
7. Chuprina V. P., Rullman J.A. C., Lamerichs $R . M . J . N$. et al. Structure of the complex of lac repressor head piece and an 11 base-pair half-operator determined by nuclear magnetic resonance spectroscopy and restrained molecular dynamics // J. Mol. Biol. $-1994-234-P, 446-462$.

8. Lamerichs R. M.J. N. Boelens R., Marel G. V. et al. H NMR study of a complex between the lac repessor headpiece and a 22 base pair symmetric lac operator // Biochemistry.-1989.28. -P. $2985-2991$.

9. Fry D. C., Byler D. Mi., Silsi $H$. Solution structure of the 45-residue MgATF-hinding peptide of adcnylate kinase as examined by 2-D NMR, ITIR, and CD spectroscopy // Ibid. $-1988-27 .-$ P. $3588-3598$.

10. Helent $C$., Lancelot $G$. Interaction between functional groups in protein-nucleic acid associations // Progr. Biophys. and Mol. Biol. $-1982 .-39$, N 1.-P. 1-68.

11. Takenaka A., Sasuda Yo. Studies on protein-nucleic acid interaction by model crystals // J. Crystallogr. Japan.1985.--27.-P. 324-336.

12. Bruskov V. I. On recognition of nucleotide bases by amino acids and peptides through hydrogen bonds $/ /$ Mol. Biol. (Russ.) - $1975 .-9$, N 2.-P. 304--309.

13. Bruskov V. I, Bushuev V. N. PMR investigation on complex formation between nucleosides and compounds modelling amino acids residues of proteins in dimethylsulfoxide $/ /$ Biofizika (Russ.). $-1977 .-24$, N 1.-F. $26-31$

14. Briskov V. 1. Model systems of protcin-nucleic acid recognition // Sc. D. Thesis. -Moscosr, 1990.-38 p.

15. Lincelot $G$., Helene $C$. Model studies between nucleic acids and proteins: hydogen bonding of amides with nucleic acid bases // Nucl. Acids Res.-1979. -6, N 3.-P. 1063-1072.

16. Lancelot $G$. Hydrogen bonding between nucleic acid bases and carboxylic acids // J. Amer. Chem. Sox.-1977. -99, N 21. P. $7037-7042$.

17. Lancelot $G$., Helen $C$. Selective recognition of nucleic acids by proteins: the specificity of guanine interaction with carboxylate ions // Proc. Nai. Acad. Sci. USA. $-1977 .-74, \mathrm{~N} 11 .-$ P. $4872-4875$.

18. Remko $M$. PCILO study of hydrogen bonds and proton Iransfer in systems 1-methyl-thymine-acetamide and 1-meihylthymine-acetic acid // Coll. Czechoslovak Chem. Commun.1981.-46. N 4.-P. 957-962.

19. Gresh N., Pullman R. A. theoretical study of interaction of guaninc and cylosine with specific amino acid side chains // Biochim. et biophys. acta.--1980.-608, N 1.-P. 47-53.

20. Zheltovsky N. V., Santoilenko S. A., Gultyaev A. P. Model study of some elements of a uucleic acid-polypeptide recognition code // Stud. biophy's-1980.-81, N 2/3.-P. $145-$ 146.

21. Gultyaev A. P., Samoilenko S. A. and Zheltovsky N. V. Spectroscopic investigation of interactions between nucleotide bases and amino acid esters in dimethylsulfoxjde // Mol. Biol. (Russ.).--1981.-15, N 6.-P. 1295-1302.

22. Zheltovsky N. '., Gultyaev A. F.. Samoilenko S. A. Investigation of the interactions of nucleic acid components with low-molccular ligands of peptidic nature // Stud. biophys.-1984.-104, N 1-3.-P. 301-302.

23. Zheltovsky M. V., Samijlenko S. P., Gubaidullin M. I., Kondratyuk $I . V$. Vibrational spectrum and structure of the solid slate complex of cylosine with N-formylglycine // Dopovidi Akad. Nauk Lkr. RSR, Ser. B (Ukrainian).--1988.N 5.-P. 72-75.

24. Zheltovsky $M . \quad V$, Samijlenko $S$. P., Kolomiets' $I . \quad M$, Kondratyuk $I . V$. Interactions of nucleotide bases with amino acid carboxylic group in dimethylsulfoxide: The model of point protein-nuclcic acid contacts $/ /$ Ibid. $-\mathrm{N} 8 .-\mathrm{P} .68-71$.
25. Kondratyuk I. V., Kolomiets I. N., Samoilenko S. A., Zheltovsky N.V. A study of complexes between cytosine and amino acid carboxylic group by NMR spectroscopy // Biopolimery i kletka. - 1989.-5, N 6.--P. $21-25$

26. Zheltovsky M. V., Samijlenko S. P., Kolomiets' I. M. et al. Investigation of interaction of hypoxanthine, xanthine and their methyl and glycosyl derivatives with amino acid carboxylic group by spectroscopic methods // Ibid. -1993.-9, N 3.P. $72-77$.

27. Zheltovsky M. V., Samijlenko S. P., Kolomiets' I. M. et al. Interactions of methyl and glycosyl derivatives of pyrimidine nuclentide bases with amino acid carboxylic group // Ibid.1994. -10, N 6.-P. 45-51.

28. Zheltovsky N. V., Samoilenko S. A., Kolomiets $I$. N. et al. Some structural aspects of protein-nucleic acid recognition point mechanisms involving amino acid carboxylic groups $/ / \mathrm{J}$. Mol. Struct. -1989.-214.-P. 15-26.

29. Kolomiets 1 . N., Kondratyuk $I$. V., Stepanyugin A. V. et al. Influence of methylation of nucleic acid purine bases on their interactions with amino acids through the carboxylic group // Ibid. $-1991 .-250 .-$ P. $1-11$.

30. Zheltovsky N. V., Samoilenko S. A., Kondratyuk I. V. et al. Recognition of purine bases and nucleosides by amino acid carboxylic group // Ibid. -1995.-344.-P. 53-62.

31. Samijlenko S. P., Kolomiets $J$. M., Kondratyuk $I$. V. of al. A proton transfer in complexes modeling recognition of nucleic acid bases by amino acid carboxylic group: spectroscopic evidences // XXIII Eur. Congr. Mol. Spectrosc. (Balatonfured, Hungary, 25-30 August, 1996).-Balaton, 1996.-J' 358.

32. Kondratyuk $I$. $V$. Investigation of physical-chemical nature of elementary processes of molecular recognition by NMR and vibrational specroscopies and computor simulation // Ph. D. Thesis.-Kyiv, 1996. -19 p.

33. Lancelot $G$. Hydrogen bonding of amino acid side chains to nucleic acid bases // Biochimie.-1977.-59, N7.-P. 587.

34. Hovorun D. M., Kondratyuk I. V. Anisotropy of amino group rotational mobility in canonic nucleotide bases // Dopovidi Nat. Acad. Sct. Ukraine. -1996. - N 10.-P. 151-154.

35. Hovorun D. M., Mishchuk Ya. R., Kondratyuk I. V. On a quantum-chemical nature of a stereochemical nonrigity of canonical bases $/ /$ Biopolymers and cell (Ukrainian).$1996,-12$, N 5. - P. 5-12.

36. Hovorun D. M., Mishchuk Ya. R., Kondratyuk I. V., Zheltovsky $N$. V. A dynamical stereoisomerism of the Watson-Crick pairs of nucleotide bases // Dopovidi Nat. Acad. Sci. Ukraine. $-1995 .-\mathrm{N} 11 .-\mathrm{P} .121-123$.

37. Hovorun $D$. M. A structural-dynamic model on spontaneous semiopen states in DNA // Biopolymers and cell (Ukrainian). $-1997 .-13, \mathrm{~N} 1 .-\mathrm{P} .39-45$.

38. Hovorun $D$. $M$. On the microstructural origin of the linear DNA // Dopovidi Nat. Acad. Sci. Ukraine. $-1998 .-\mathrm{N} 5$ (in press).

39. Kolomiets $I . M$. Investigation of specific interactions of amino acid carboxylic groups with nucleotide bases, nucleosides and their methyl derivatives by means of optical spectroscopies // Ph. D. Thesis.-Kyiv, 1996.-21 p.

40. Samijlenko S. P., Kondratyuk $I$. V. NMR investigations on the role of glycosylic $O H$ groups in complexes modelling point protein-nucleic acid contacts // Spectroscopy of Biological Molecules: Modern Trends, Annex.-Madrid: Univ. Nac. Educ. Dist., 1997 -P. $67-68$.

41. Singer B.. Antoccia A., Basu A. K et al. Both purified human 1,N6-ethenoadenine-binding protein and purified human 3 methyladenine-DNA glycosylase act on 1,N6-ethenoadenine and 3-methyladenine // Proc. Nat. Acad. Sci. CSA. - 1992.89 , N 20 .-P. $9386-9390$. 
42. Ishida T., Doi M., Ueda $H$. et al. Specific ring stacking interaction on the tryptophan-7-methylguanine system: Comparative crystallographic studies of indol derivatives-7-methylguaninc base, nucleoside, and tucleotide complexes $/ / \mathrm{J}$. Amer. Chem. Soc. $-1988 . \cdots 110$, N 7.-P. $2286-2294$.

43. Rould M. A., perona J. J., Soll D., Steitz T. A. Structure of E. coli glutaminyl-tRNA synthetase complexed with tRNA ${ }^{\text {Gin }}$ and ATP at 2.8 A resolution // Science.-1989.-246.P. $1135-1142$

44. Perona J. J., Swanson R. N., Rould A. M. et al. Structural basis fur misaminoacylation by mutant $E$. coli glutaminyl-tRNA synthetase enzymes // Ibicl.--P. 1152-1154.

45. Biou V., Yaremchuk A., Tukalo M., Cusack S. The 2.9 A crystal structure of $T_{\text {s }}$ thermophitus seryl-tkNA synthetase complexed with RNA $^{\text {Ser }} / /$ Ibid.-1994.-263.-P. 14041410.

46. Belrhati H., Yaremchuk A., Tukaio M. et al. Crystal structures at 2.5 Angstrom resolution of seryl-1RNA synthetase complexed with two analogs of seryl adcnylate // Ibid.-P. 1432-1436.

47. Koepke J., Maslowska M., Heinemann U., Saenger W. Threedimensional structure of ribonuclease $T_{1}$ complexed with guanylyi-2',5'-guanosine at 1.9 A resolution $/ / \mathrm{J}$. Mol. Biol.1989.-206.-P. $475-488$.

48. Namba K., Pattanayek R., Stubbs $G$. Visualization of proteinnucleic acid interactions in a vins. Refined structure of intact tobacco mosaic virus at 2.9 A resolution by $X$-ray fiber difiraction // Ibid.--1989.-208.-P 307-325.

49. Luisi B. F., Xu W. X., Otwinowski $Z$. et al. Crystallographic analysis of the interaction of the glucocorticoid receptor with DNA // Nature.-1991.-352, N 6335.--P. 497-505.

50. Klimasauskas S., Kumar S., Roberts R. J., Cheng X. Hhal methyltransferase flips its target base out of the DNA helix // Cell. -1994. - 76.--P. 357-369.

51. Liu L., Santi D. V. Mutation of asparagine 229 to aspartate in thymidy!ate synthase converts the enzyme to a deoxycytidylate methylase // Biochemistry.-1992.-31, N 22.—P. 51005104.

52. Zundel $G$. Hydrogen-bonded systems with large proton polarizability due to collective proton motion as pathways of protons in biological systems $/ /$ Electron and proton transfer in chemistry and biology / Eds A. Muller et al--Amsterdam: Elsevier, 1992.-P. 313-327.

53. Iliadis $G$., Zundel $G$., Brzezinski B. Aspartic proteinase Fourier transform IR studies of the aspartic carboxylic groups in the active sitc of pepsin // IEBS I ett.-1994.-352.P. $315-317$.

54. Zundel $G$. Hydrogen-bonded systems as proton wires formed by sicie chains of proteins and by side chains and phosphates // Transport through membranes: Carriers, channels and pumps / Eds A. Pullman et ai.-Dordrecht: Kluwer Acad. Publ., 1988.-P. 409--420.

55. Zundel $G$. IHydrogen-bonded chains with large proton polarizability as charge conductors in proteins. Bacteriorhodopsin and the F subunit of $E$. coli // J. Mol. Struct.-1994. -322.P. 33-42.

56. Brzezinski B., Radziewski P., Olejnik J., Zundel G. An intramolecular hydrogen-bonded system with large proton polarizability - a model with regard to the proton pathway in bacteriorhodopsin and other systems with collective proton motion $/ /$ Ibid. -323 . -P. $71-78$.

Received 01.07.97 